\title{
Introduction
}

\section{HISTORICAL SCHOLARSHIP}

The Farther Adventures of Robinson Crusoe; Being the Second and Last Part of His Life, and of the Strange Surprizing Accounts of His Travels Round Three Parts of the Globe was published by William Taylor on 20 August 1719, approximately four months after the appearance of The Life and Strange Surprizing Adventures of Robinson Crusoe. ${ }^{1}$ It is clear from the final pages of the first volume that Defoe was already at work on the sequel and had thought out much of what he was going to do at least up to the point of Crusoe's learning what had become of his island and his leaving the island and arriving at Brazil. He also promised "new Adventures of my own, for ten Years more." The second edition of The Life and Strange Surprizing Adventures had been published with an image of a large ship on the title page, and this logo was used for the first edition of The Farther Adventures. While this was partly an image of William Taylor's printing house (at the Ship in PaterNoster-Row), it was also suggestive of a work that would be about voyages. The subtitle itself imitated the titles of a variety of genuine voyages, from William Dampier's A New Voyage Round the World (1697) to Woodes Rogers's A Cruising Voyage Round the World (1712). A second edition appeared in the same year, a third and fourth in 1722, and a fifth in 1726, but it appears that, from the very beginning, the second volume was sold along with the first. ${ }^{2}$

Although this sequel has many new adventures, it functioned, in part, as a kind of commentary upon The Life and Strange Surprizing Adventures. Perhaps this is nowhere clearer than in the consideration of exile from the world, the concept of political power, and the notion of self-discipline raised in the discussion with the Prince when Crusoe is in Tobol'sk toward the end of The Farther Adventures. There, confronted with the far reach of the power of the Tsar, Peter the Great, Crusoe brings up the absolute power he had on his island when he was ruling over his goats and his pets. What was originally an ironic picture of political power now becomes more aestheticized and distanced. Imagined as a set verbal description or tableau, it became a scene depicted by most of the illustrators of Defoe's novel. In The Farther Adventures, Defoe presents the notion of his absolute monarchy as a 
memorable parable about the futility of power. The fourth edition of The Life and Strange Surprizing Adventures had already appeared by the time of the publication of The Farther Adventures, and undoubtedly, Defoe expected that the powerful verbal images evoked by his first volume would carry resonance in the second.

The process is that of allusion and expansion. In the context of the power of the Tsar of Muscovy, Peter the Great, to exile his subjects or, indeed, to murder his subjects, Crusoe's own power over his pets seems like a sly joke, while his exile from the world retains its seriousness. In this case, the notion of a literal isolation from the world is allowed to expand into the larger notions of political, social, and moral exile. The Prince has found in his forced withdrawal from a world of pleasure and power an opportunity for contemplation of the futility of his former state, particularly from the standpoint of his Christian faith and his belief in the immortality of the soul. Both Crusoe on his island and the Prince in his exile are given no choice about their conditions, but whereas Crusoe opts to leave his island as soon as the opportunity arises, the Prince regards Crusoe's offer of escape as a possible temptation from the Devil. He chooses to remain in his exile, and is thus, much more than Crusoe, like one of the hermits of early Christianity who chose isolation as part of their way toward salvation. In Serious Reflections during the Life and Surprising Adventures of Robinson Crusoe (1720), Crusoe would reject the notion of physical isolation as a way toward achieving greater philosophic and religious strength in favor of the notion that the mind was capable of as much solitude in crowded cities as in a cave. But whatever suggestion there may have been of Crusoe as a religious solitaire in the first volume is given less play, but far more resonance, in The Farther Adventures.

This process of expanding and reconsidering the themes and angles of vision provided by The Life and Strange Surprizing Adventures is present from the beginning. The reader learns more about Crusoe's "wandring Spirit" (141) as well as about the fanciful nature of his waking imagination and actual dreams as he longs to return to his island. ${ }^{3}$ We come to understand how impulsive he has always been. Often viewed as an "Everyman" or the typical, commonsensical Englishman, Crusoe emerges in this second part as a far more eccentric figure than he appears under the limited stress of his isolated island life. In breaking his ties with his family to seek a more eventful life than that offered by accepting the "Middle Station" and remaining in York, Crusoe had already displayed a certain antisocial streak, but this becomes far more pronounced in The Farther Adventures. He will make himself so obnoxious to most of the crew of his nephew's ship that they will set him ashore in the Far East rather than sail with him. He will blow up a pagan idol even if this action means that he will bring down the wrath of the entire Tatar nation upon his caravan. If the reader of the first volume is carried along by Crusoe's narrative to place almost entire confidence in what he says, the reader of the second volume has to have moments of doubt.

Once the voyage is underway, Defoe picks up the themes surrounding the ideas of survival that had been at the core of the first volume. Crusoe's ship encounters 
not one but two ships that raise questions about the need to sustain life. The first is a ship that has caught fire and left its crew and passengers with the likely prospect of dying at sea from thirst and starvation. There is no isolation here, just the prospect of a terrible fate. In the depiction of the second ship, there is actual death by starvation: it is the fate of one of the passengers, the mother of a young man and mistress of a young woman who acts as her Maid. This is amplified later by the Maid's description of her own feelings as she grew weaker every day without food. She concludes that she would have resorted to cannibalism had she the opportunity. As Defoe knew, there had been cases of cannibalism that had resulted from wrecks at sea. Tried for murder in Holland, the surviving crew had been acquitted. ${ }^{4}$ Under conditions of necessity, the usual laws of society were suspended. Crusoe had no need to resort to cannibalism on his island. He had been able to overcome the possibility of starvation by looting food, along with tools necessary for life, from the wrecked ship. Yet the larger themes are present in the first volume, and Defoe thought it would be well to expand the possibilities inherent in Crusoe's situation.

One of the ways in which he extrapolated upon this theme had to do with an interest in the ways in which human emotion might be depicted through a rendering of gestures and facial expressions. Whether Defoe simply shared this interest with his age or had done some careful reading in works such as Charles Le Brun's rendering of facial expressions and the new aesthetic of the Abbé JeanBaptiste Dubos is difficult to say. But as Michael Fried argued, the age seemed to delight in the expression of inner emotions in paintings that created the frame as a kind of window through which the subject might be observed engrossed in his or her emotions. ${ }^{5}$ Dubos argued for the importance of gesture as having a significance that was perhaps greater, in some respects, than that of language itself. ${ }^{6}$ At any rate, the scene involving the rescue of the passengers from the ship destroyed by fire has no parallel in any of Defoe's fiction:

It is impossible for me to express the several Gestures, the strange Extasies, the Variety of Postures which these poor deliver'd People run into, to express the Joy of their Souls at so unexpected a Deliverance; Grief and Fear are easily described; Sighs, Tears, Groans, and a very few Motions of the Head and Hands make up the Sum of its Variety: But an Excess of Joy, a Surprize of Joy has a Thousand Extravagancies in it; there were some in Tears, some raging, and tearing themselves, as if they had been in the greatest Agonies of Sorrow, some starkraving and down-right lunatick, some ran about the Ship stamping with their Feet, others wringing their Hands; some were dancing, some singing, some laughing, more crying; many quite dumb, not able to speak a Word; others sick and vomiting, several swooning, and ready to faint; and a few were Crossing themselves, and giving God Thanks. (22)

The visual and tonal aspects of this description should be obvious. Defoe creates what might be regarded as a cinematic effect, using language to go beyond what might only be suggested by a painting of such a scene. 
Defoe had long been fascinated by the observation made by Robert Wild, "For sudden Joys, like Griefs confound at first," and he has Crusoe quote this line and experience emotional crises brought on by "sudden Joys" in The Life and Strange Surprizing Adventures. ${ }^{7}$ In the first volume, he also had dwelled upon Friday's wild gestures on discovering his father among the prisoners from the cannibals. But the rendering in The Farther Adventures is quite distinct, with a particular emphasis on "Postures" depicting the emotions, suggestive of the engraved illustrations of Charles Le Brun in his book on the ways in which the emotions reveal themselves in facial expressions. ${ }^{8}$ It is all part of Defoe's revisiting his text and realizing some of the possibilities that, as he thought, had not been sufficiently exploited. In this case, it is the visual that he tries to emphasize-the novel as the verbal recreation of visualized scene. There were a number of painters who had attempted something similar: scenes of shipwreck in which those who have been saved show various emotional reactions. ${ }^{9}$ Defoe tried to give the reader a kind of tour of the possible emotions involved, focusing on individual gestures and feelings. When he came to allow the Maid to describe her sensations as she was starving, Defoe was more interested in her inner emotions than in outward manifestations.

Another element of expanding along specific lines from The Life and Strange Surprizing Adventures has to do with the political theme. As has been seen, within The Farther Adventures, in the discussion with the exiled Prince in Tobol'sk, Crusoe repeats his notion of himself as the absolute monarch of his island, reifying what is suggested with irony in the first part. But Defoe clearly wanted to firm up the political ideas by dramatizing the ways in which, through external pressure, a society may establish itself despite political wrangling, in this case the threat posed by the cannibals who invade the island. It is the arrival of the cannibals that operates as the crucial force that draws the inhabitants together, even if there is also a degree of domestication achieved somewhat earlier through the relationships of the Englishmen with their native women. The English colonies of the West Indies had followed a similar path, first being the lairs of pirates and gradually settling down into relatively peaceful economic units. ${ }^{10}$ In a sense, this theory about the formation of a state was part of the Enlightenment theory of history. Sir Walter Scott's series of historical novels on the conflicts within Great Britain ends with The Antiquary, in which the threat of Napoleon's invasion brings together in a common cause characters with extremely disparate viewpoints and personalities. ${ }^{11}$

While the three Englishmen led by Will Atkins are in revolt against the Spaniards and their two fellow Englishmen, there is little ideological basis for the anger and aggression that they display. When Atkins and his followers attempt to destroy the agricultural improvements of the two industrious Englishmen, Crusoe notes that they "sack'd and plunder'd every thing, as compleatly as a Hoord of Tartars would have done" (47), suggesting that such barbarism and violence were simply part of their character. ${ }^{12}$ Unlike the Spaniards, they do not have their emotions under anything resembling rational control. However, when they have to fight the cannibals who eventually come to the island, they prove to be resourceful and courageous. Defoe clearly admired unruly characters such as Atkins-characters like 
his eponymous hero Captain Singleton, who were too resentful of authority to fit into the rigidly structured army or navy of contemporary England. Defoe viewed them as the type of adventurers who, under the right circumstances, might achieve great things. Being neglectful farmers and indifferent workers, they pose a threat to the nascent colony. Only after they recognize their stake in society, through their wives, do they become more tractable ("civiliz' d" [70]) citizens. Defoe suggests that their conversion to Christianity might help bring them closer to understanding their civic responsibilities.

Another motif developed out of The Life and Strange Surprizing Adventures arises from the imagery associated with war. Defoe had delineated in the language of seventeenth- and eighteenth-century warfare Crusoe's fight against the cannibals when the Spanish Captain and Friday's Father are rescued, as well as the struggle against the wolves in the Pyrenees. But war plays an even more important role in The Farther Adventures, first in the battle of the two tribes of cannibals who land on the island (54-55); second in the battles fought directly with the cannibals (74-81); third in the "Massacre of Madagascar" with its echo of the famous siege of Magdeburg on 20 May 1631 during the Thirty Years' War (164-165); and finally in the repeated struggles against the "Tatars": those who attack at the beginning (218-224), those who follow Crusoe and his caravan across Siberia to take revenge for Crusoe's destruction of their idol (235-236), and those who are interested in looting the caravan (253-255). Defoe may have already been working on his Memoirs of a Cavalier, published in May 1720, and other military memoirs. At any rate, what appears more or less as a metaphor in the first volume becomes a full account of battles involving the natives of three continents.

The most elaborate of these is the "Massacre of Madagascar," which entails an attempt to take revenge upon the natives after one of the sailors, Thomas Jeffry, is killed and his body put on display by the natives. But the cause of this entire affair is the rape of a young woman by this same Thomas Jeffry. As Defoe presents the event, it is a typical scene out of the history of colonial appropriation. Thomas Jeffry apparently does not think his rape of the woman amounts to an act of any social consequence, but it violates the truce that has been established at the beginning of the contacts between the Europeans and the natives. To the sailors, the important thing is that Thomas Jeffry has been killed and his body mistreated. They commence a complete slaughter of as many of the villagers as they can find. Crusoe's sympathy is mainly with the villagers, yet the language ("The Sight of their poor mangled Comrade so enrag' $d$ them ... that they swore ... they would be reveng'd") allows some sympathy for the sailors as well. On the other hand, the picture of the "Terror and Consternation" of the natives and the identification of those killing and burning the village as "our English Butchers" (159) leaves little doubt where the reader's sympathy should lie. Defoe deliberately borrowed from an art manual depicting what was clearly a scene from the siege of Magdeburg, and once more his focus is on creating an emotional effect for the reader. ${ }^{13}$ Crusoe delineates his reaction ("My very Soul shrunk within me, and my Blood run chill in my Veins" [159]) as well as the various postures and cries of those fleeing from the 
slaughter. He is moved by this "piteous Spectacle" (160) and horrified by the genocidal fury of the sailors, who have vowed, "we'll root out the very Nation of them from the Earth" (160). In some sense, these attitudes are the reverse of Crusoe's unwillingness to engage in a mass slaughter of the natives in The Life and Strange Surprizing Adventures. The Spanish Captain voices similar reluctance in regard to the cannibals of the Caribbean.

The cannibalism that, in the first volume, had so outraged Crusoe and yet eventually led to a more measured response, finds a parallel development in the sequel with an even more explicitly ameliorating comparison between the behavior of the cannibals and that of European combatants. It is chiefly the fear of being devoured that impels the Spaniards, Will Atkins's group, and the two less aggressive Englishmen to join together, and as we have already mentioned, Defoe introduces the notion of cannibalism among Europeans in the extreme situation of those abandoned at sea. Although the horror of cannibalism among the natives is still at the fore, the carnage among the natives after their warfare is not very different from that of any battle, whether among the Caribs or the Europeans. On observing the corpses of the two warring tribes of cannibals on the "Field of Battle" (55), the Spanish Captain found

about two and thirty dead Men upon the Spot; some were kill'd with great long Arrows, some of which were found sticking in their Bodies; but most of them were killed with their great Wooden Swords, sixteen or seventeen of which they found in the Field of Battle; and as many Bows, with a great many Arrows: These Swords were strange great unwieldy Things, and they must be very strong Men that us'd them: Most of those Men that were kill'd with them, had their Heads mash'd to pieces, as we may say, or as they call it in English, their Brains knock'd out, and several their Arms and Legs broken; so that it's evident they fight with inexpressible Rage and Fury. (55)

Thus the reader is given an unsettling vision of warfare as an example of brutal rage. Yet when the three Englishmen voyage to the mainland and find themselves presented with five women and eleven men to serve as food for their voyage back, "just as we would bring so many Cows and Oxen down to a Sea-Port Town, to victual a Ship," these "brutish and barbarous" (65) sailors are nauseated at the very notion that they might want to become cannibals. Warfare, then, though horrific, is within the area of normative human behavior; cannibalism, though acknowledged to be a possibility among all human beings, nevertheless possesses an element of the grotesque - of an action at the extreme of human behavior.

The potentiality for the island becoming a colony was present in Crusoe's willingness to allow the three English mutineers to settle there, but in The Farther Adventures, it is developed as a major theme. Not only do the Englishmen and their native wives have numerous offspring, but Crusoe also sends additional inhabitants from Brazil, including a prospective settler with sugarcane to plant. He also has sent cattle and craftsmen. He has divided up the land, distributing separate sections to the inhabitants, and finally he gives them complete freedom of action. 
Why, then, does the colony seem to be failing at the end? The miscarriage of the colony may have come as an afterthought, but it may also have something to do with Crusoe's refusal to nurture it. Defoe leaves the general impression that governments function best with a strong, dedicated leader. ${ }^{14}$ Crusoe speaks of what he might have done (148) to have established it on firm foundations, how he might have taken out a patent as governor and helped them. The failure comes in these pages along with a condemnation of his "wandring Spirit." Defoe could have chosen to write an entertaining novel about Crusoe's becoming "the Patron of those People," but he apparently felt that this would not have interested his readers as much as the further travels and adventures that he decided to provide.

Perhaps the most important continuation from The Life and Strange Surprizing Adventures was the Christian theme that had so informed Crusoe's stay on the island. It takes several new directions. In the conversion of Will Atkins and his native wife, Defoe turns to the Christian motif of the converted sinner. Atkins has shown himself to be violent and even murderous - a character very different from Crusoe, the merchant and Brazilian planter. Yet Defoe presents his conversion in a moving manner. It is of some interest that what was clearly intended as a fully annotated edition of the first two volumes by the Hydrographer of the Naval Chronicle (1815) omitted this section entirely. Did it seem out of keeping with this editor's notion of polite literature and religion by this time? Or was Defoe's sympathetic treatment of miscegenation the problem? Certainly the dialogue between Atkins and his wife is moving enough. The agency of this conversion is a Catholic priest, who preaches an ecumenical Christianity and marries the Englishmen and their wives. Why Defoe should have been advocating such a broad concept of Christianity at this time is difficult to say. The exiled Prince in Tobol'sk, certainly a member of the Russian Orthodox Church, also finds his faith increased as a consequence of his exile and is set forth as an idealized Christian.

In addition to these themes continued from The Life and Strange Surprizing Adventures, Defoe also continues the character of Crusoe's ideal servant and companion, Friday. Yet he kills him off (208) on the voyage from his island to the Bay of All Saints, the place of his old plantation in Brazil. It is clear that Defoe wanted Crusoe to travel alone through the Far East and then across Siberia and to facilitate the introduction of new characters. But Friday had been a rich character, and it is not entirely clear why Defoe would have been willing to do away with this sympathetic figure, whom Crusoe says he "so entirely lov'd and valu'd" (143). Perhaps Defoe was annoyed by comments similar to Charles Gildon's criticism of Friday's way of speaking. But Gildon's attack was not to appear until 22 September 1719, a month after the publication of The Farther Adventures. At any rate Defoe, introduced a defense of his rendering of Friday's dialect and some commentary on language and gesture. Not only did Defoe argue that the addition of "ee" at the end of words was common to some natives' rendering of English, but he also has Friday killed on board the ship in the act of interpreting a gesture-the natives' showing the Europeans "their naked Backsides, just as if in English, ... they had bid us kiss__— (142). And this is followed by a discussion of the peculiar language of a 
native whose manner of speaking is described as "so odd, all Guterals" (144). In The Farther Adventures, Friday is never allowed to speak, and his death in the midst of a discussion of language and gesture cannot be without significance.

\section{Literary ANALYSIS}

Although so much of The Farther Adventures is an extension of the first volume, the essential thrust of this sequel is in the direction of adventures and travel and away from an exploration of the inner life. In some sense, Defoe's ability to hold the attention of readers during Crusoe's solitary stay on the island amounted to a fictional tour de force. If almost all of Defoe's fictional characters tend to be distinguished by an inner isolation, they are never bereft of a social environment; even $\mathrm{H}$. F., who wanders the streets of a nearly deserted London during plague time, has some human contacts. Unless one desires to view Crusoe's discovery of the single footprint, and after that, his observation of the cannibals who land on the island, as the embodiment of a kind of relationship with other human beings, approximately 190 pages of the first edition explore Crusoe's isolated island life before the arrival of Friday. It was not an achievement that Defoe wanted to or would have been able to repeat. He had other interests-in travel, in Britain's social, moral and political problems, in economics - all of which were to occupy his mind during the five remarkably productive years during which he produced his major fictions.

At least some of these interests were probably driven by agreements that Defoe made to write certain works. Among these was the writing of a large section of an atlas that was eventually published in 1728 as Atlas Maritimus \& Commercialis. In the back of the first edition of The Farther Adventures, among advertisements of the books he was selling, William Taylor listed as item fifteen among the folios "A new general Atlas, with above 40 large Maps, printed on an Elephant Paper . . . in the Press and in great Forwardness." Taylor was to die in 1722, long before the appearance of this atlas, but on the title page he was still listed among the publishers under the rubric "the Executors of William Taylor deceas'd." This meant that Defoe was engaged in researching the geography and economics of what was known of the entire world at the time. Works such as his Tour thro' the Whole Island of Great Britain (1724-1727), and even A Plan of the English Commerce (1728), appear to be the products of the reading that he was doing in connection with this largescale work. In some sense, Defoe's willingness to embrace a project involving an understanding of the entire earth may have helped him achieve some of the expansiveness present in his works of fiction.

In 1724 Defoe was to publish a fictional version of the circumnavigation of the world, A New Voyage Round the World, by a Course Never Sailed Before, but if Robinson Crusoe does not manage to travel all the way around the globe in The Farther Adventures, he does go to areas that were of great interest to his reading audience. His voyage to his island and subsequently to Brazil covered geographical material already offered in the first volume, but his travels to Madagascar and the Far East and across Siberia opened up new possibilities for exploration as well 
as adventure. In this respect, Defoe, as the author of The Farther Adventures, may be seen as the true inventor of the adventure novel-a genre that continued to provide excitement for readers in the novels of Henry Rider Haggard and in the far more subtle hands of Joseph Conrad during the nineteenth and twentieth centuries. ${ }^{15}$ Of course, there were progenitors enough, but the realist technique of Defoe, combining the presence of what Ian Watt called "formal realism" with the grounding of the narrative in a combination of historical and economic realities, gave a unique blend to the work. ${ }^{16} \mathrm{He}$ also added to the genre a resonance of economic exploitation and an ambivalent attitude toward colonialism that continued to echo in the work of later novelists.

The excitement in such material did not escape Defoe's attention. In the year following The Farther Adventures, he published The Life, Adventures, and Pyracies, of the Famous Captain Singleton. Drawing upon the myths that had formed around the famous pirate Captain Avery, he has his protagonist settle for a while in Madagascar, where Avery was supposed to have established a pirate kingdom. ${ }^{17}$ But just as he had Crusoe travel across the little-known steppes of Siberia, Defoe has Singleton march across an Africa that was still little explored. At one point in his journey, Singleton encounters a kind of ancestor of Conrad's famed Kurtz in Heart of Darkness, the exemplar of the colonist who has "gone native" and who, in his thirst for gold or success, appears to have lost his sense of proportion. ${ }^{18}$ Crusoe does not encounter the exotic beasts who attack Singleton, but he does come across strange idols and the wild Tatars. And as familiar as the colony of Brazil may be to Crusoe, the belligerent tribe he and the ship's crew encounter in the battle that results in the death of Friday clearly belongs to some unknown linguistic group. In short, the earth still contained mysterious peoples and places, and Defoe was willing to use his fictive imagination to exploit them.

There is certainly nothing new in Defoe's attempt to set his hero in motion across the world. The ancient model for this was Homer's Odyssey and his hero's long journey around the Mediterranean and his return to his beloved Ithaca. This kind of voyaging was borrowed by the Greek romance, which in turn influenced subsequent romances based on their model. Defoe, of course, provides no strange monsters to harass his protagonist in the manner of Homer, and he adhered to a realist model in his delineation of various countries. From this standpoint, it is hardly odd that adaptations of the first two volumes of Robinson Crusoe were used to teach geography to young men and women. ${ }^{19}$ In The Farther Adventures, more than in the original volume, Defoe created a strong sense of movement in time and space. He does this in a mechanical manner toward the conclusion:

From hence we came to Lawrenskoy the $3 \mathrm{~d}$ of July ... we embark'd the 7 th, and arriv'd all safe at Arch-Angel the 18th, having been a Year and five Months and three Days on the Journey, including our Stay of eight Months and odd Days at Tobolski...

We sailed from Arch-Angel the 2oth of August the same Year, and after no extraordinary bad Voyage, arriv'd in the Elbe the 13 th of September.... 
To conclude, having stay'd near four Months in Hamburgh, I came from thence over Land to the Hague, where I embark'd in the Pacquet, and arriv'd in London the 1oth of January, 1705, having been gone from England ten Years and nine Months. (258)

Of course, had the novel consisted of this kind of chronicle structure (this happened and then that happened) it would have been the kind of narrative that Defoe always criticized. Nevertheless, he provides this arrival-departure movement through time and space to anchor the novel in the real-in a necessary calendric and geographic reality.

From this standpoint, it is also necessary to consider The Farther Adventures along with the rest of Defoe's fiction as existing in both a historical time and a contemporary time. As history may be said to exist in the text, Crusoe sets out on his voyaging during the reign of William III, shortly after the death of Queen Mary on 28 December 1694. He returns on 10 January 1705 during the reign of Queen Anne. It was a period of marked involvement in trade to the Far East, with the East India Company battling with the New East India Company for control. Two products, Chinese porcelain objects and tea, were to become part of contemporary literature, the first in the famous "china scene" from William Wycherley's The Country Wife (1675) and the second in Nahum Tate's Panacea: A Poem upon Tea (1700). Even more famously, Alexander Pope in his Windsor Forest (1713) and in the expanded version of The Rape of the Lock (1714) would also treat the products of India and China as new and vital elements in the culture. All the places to which Crusoe travels, from Madagascar and Bengal to China, were of intense interest to Defoe's readers from the standpoint of trade. As an independent trader to Indonesia and other Asian nations, he is engaging in the kind of activity that the Old East India Company was trying to monopolize. From some standpoints, then, there is a violation of law in the activities of Crusoe and his partner, and when they purchase a ship formerly owned by those who might be considered pirates, though they themselves are certainly not pirates in any literal way, there is something of a play between outright piracy and conducting a trade that is usually plied by a legal joint stock company trying to uphold its monopoly.

Although some of the ironies in these events seem to arise from the accidents of fate, in fact, of course, almost everything that happens is based on cause and effect and on Crusoe's character. He leaves England to follow his "wandring Spirit" (148), the restlessness that drove him away from his home at the beginning of his adventures. Defoe depicts this at the beginning of The Farther Adventures in providing Crusoe with an imagination that is capable of creating waking visions. In his "Extasies of Vapours," he would imagine himself on the island by his "old Castle" with "my old Spaniard, Friday's Father, and the reprobate Sailors I left upon the Island" (9). Small wonder that Coleridge and the Romantics loved Robinson Crusoe. The protagonist is capable of transporting himself to his island in much the same way that Keats was able to be out in the night with the bird in his "Ode to a Nightingale." After the death of his wife, the self-sufficient farm 
in Bedfordshire is incapable of excluding the knowledge that, outside his small world, there is the "daily Circulation of Sorrow, living but to work, and working but to live" (13).

More than in the first volume, Crusoe appears to be an enthusiast-someone who insists on acting upon his impulses. He disapproves of what the sailors did in the "Massacre of Madagascar," but does he truly have to make himself so obnoxious to the crew that they insist on abandoning him in Bengal? And his insistence upon blowing up the Tatar idol brings down upon the other members of the caravan the wrath of much of the Tatar nation. He refuses to admit to his action when everyone is questioned about it. And he continues steady in his lie, despite the suffering that he brings upon the remainder of those in the caravan. He is also stubborn in his opinions, refusing to be impressed by a Chinese civilization that had already convinced many of those in the West of its virtues. To Crusoe, China is a barbarous land, a nation run by a tyrant; its touted scientific advances are distinctly inferior to those of the West. He does not think of the Great Wall as a stunning historical achievement but simply as an antiquated type of fortification. Behind the system of government by a class of mandarins, often extolled as a group of learned philosophers, he sees a general poverty and meanness. ${ }^{20}$ In the character of Crusoe, there is a kind of stubborn refusal to conform, accompanied by courage and an ability to lead. He also warms to kindness and generosity and has true admiration for the principles of the Prince exiled to Tobol'sk. What he feels and thinks and the actions he takes upon his impulses drive the movement of the novel.

If he is more defined by his actions than the introspective figure we encountered in The Life and Strange Surprizing Adventures, oddly enough, the Crusoe of The Farther Adventures is more of an observer and a listener. The accounts of the two ship disasters that Crusoe's ship comes across focus on the dramatic experiences of those undergoing fear and deprivation. As mentioned earlier, Crusoe carries the reader into the events with their vivid emotions and feelings. Then we have the narrative of the Spanish Captain, followed by the conversion of Will Atkins and his wife by the French Priest. The conversion is observed through a hedge by a mainly passive but emotionally moved Crusoe. It is not until after the "Massacre of Madagascar" (165) and his abandonment in Bengal that he emerges as a figure of action. Yet even as he resumes his life as a merchant in the Far East, he has to be prodded out of a kind of paralysis by his partner, the English Merchant.

As a European who refuses to be impressed by Chinese culture, and as the leader of the plot to blow up the Tatar idol, Crusoe does show himself in a new light. In the first case, he stands as a defender of Western Christian culture, refusing to join in the widening contemporary myth of the wise Chinaman. He presents a world that, compared to contemporary England and France, had to be seen as impoverished. His image of the life of the Mandarin whom he encounters as "a perfect Don Quixotism, being a Mixture of Pomp and Poverty" (209) refuses to yield to any concept of cultural relativism. It is in this obstinate rejection of standards other than those of his native land that Crusoe seems most stubbornly English. As for his Christian chauvinism in blowing up the pagan idol, here too he seems far from 
the Crusoe who, after considerable thought and emotional struggle, was willing to grant the inhabitants of the Caribbean their cultural difference.

Although Defoe seemed to need little more than a vast blank section on a map to set his imagination working, in writing The Farther Adventures he obviously needed to know a great deal more about the world than he did in composing the first volume. Much of his information may have come from ephemera such as manuscript newsletters. As the translator of foreign news for the publisher Nathaniel Mist, he probably went through reams of such material on a daily basis between 1716 and 1719. Only a small part of these kinds of writings - those that might have some interest for the British audience-would actually appear in British newspapers, and then in a summary paragraph.

That Defoe knew a considerable amount about Brazil and sugar manufacturing was obvious from The Life and Strange Surprizing Adventures. Such information may have come from conversations with merchants as well as through reading economic tracts. His knowledge about the activities of the Inquisition in Brazil, leading to the passages in The Farther Adventures involving the smuggling of a "Heretick" (146) and his family off the island, probably owes something to his involvement with reading and writing contemporary journalism.

Some of Defoe's sources may have involved discourses with seamen and merchants rather than printed materials. Robert Drury's father lived very near Defoe in Stoke Newington, and Robert might have given him information about Madagascar. ${ }^{21}$ Defoe exchanged several letters with Captain Thomas Bowrey and apparently went to see him. ${ }^{22}$ Bowrey spent decades in India engaging in the kind of trading to Indonesia with which Crusoe involves himself. ${ }^{23}$ Similarly, it is possible that the Scottish merchant who aids Crusoe in blowing up the idol may have had a counterpart in some of the many merchants Defoe met in his trips to Scotland. But, to repeat, it is likely that much material in The Farther Adventures was connected with his work on Atlas Maritimus, which involved imagining foreign lands through maps and whatever written information was available.

In writing the notes to The Farther Adventures, we have assumed that Defoe read as widely as possible in travel literature and that it would be an error to dismiss any sources that might have been available to him. Although the catalog of his library is far from being entirely reliable as an indicator of his reading, it does contain a number of works involving travel to the Caribbean and the Far East. ${ }^{24}$ Defoe was a great reader of voyages and was certainly familiar with the materials in the collections of Richard Hakluyt and Samuel Purchas. ${ }^{25} \mathrm{He}$ almost certainly read Louis Le Comte's Memoirs and Observations ... Made in a Late Journey through the Empire of China (first French edition 1696), with its mixture of admiration for Chinese culture and ideas about China's military backwardness. At the end, Le Comte concludes that China has not produced anyone approaching greatness in "speculative science," and he cannot help but think that Louis XIV would be able to conquer China easily enough with his European army. ${ }^{26}$ In addition to this work by Le Comte, Defoe also seemed familiar with Le Comte's unsuccessful attempt at achieving acceptance from the Vatican of some of the Jesuit's methods 
used to convert the Chinese to Christianity, including the acceptance of ancestor worship as a relatively harmless ritual. ${ }^{27}$ Another possible source for Defoe was John Ogilby's elaborately illustrated translation and collection of voyages to China, including works by Johan Nieuhof and Athanasius Kircher. ${ }^{28}$ Of course, Defoe goes far beyond Le Comte in his criticism of China and of those who admired this seemingly well-ordered Empire. As noted previously, the image of the wise Chinese was already well established by 1719 , and for the most part, Defoe remained skeptical. ${ }^{29} \mathrm{He}$ has Crusoe regard the Emperor as a tyrant, Chinese religion as idolatry, and the economic system as productive of a crushing poverty.

For Crusoe's journey through Siberia to Archangel, Defoe almost certainly consulted Evert Ysbrants Ides, Three Years Travels from Moscow Over-Land to China (London, 1706), with its description of the various Mongol tribes scattered through this vast terrain. ${ }^{30}$ Although Defoe reversed the direction of Ides's journey to China, Crusoe actually follows the caravan route traced in the map that accompanies this work. But it is clear from the variation in spelling of place names that Defoe had other maps at his disposal. It is also apparent that Defoe had considerable knowledge of Russia and its empire. Peter the Great would have been a person of considerable interest to England during the historical time that Crusoe is supposed to be crossing through the Asian territories of Russia. ${ }^{31}$ Defoe opened his Consolidator (1705), a work roughly contemporary with Crusoe's return to England, with remarks on Peter's journey to Europe and his attempt to bring enlightenment to his nation. Charles XII of Sweden had defeated Peter's army at Narva in 1700, but Defoe thought that such setbacks would not be permanent, that Peter's armies would eventually become more seasoned and that the Swedes would teach the Russian army how to fight. By 1719 Peter had consolidated his power over Russia, and the basis for the Peace of Nystad, to be signed in August 1721, which gave Russia power over lands formerly controlled by Sweden, was already in place. But the crueler side of Peter's nature had been displayed in the treatment of his son Alexis, who was accused of plotting against his father and was tortured to death in 1718. Since Great Britain had been involved in the Great Northern War since 1701, interest in Russia would have been high. The image of that nation as a place that exiled good people such as the Prince in Tobol'sk was closer to attitudes of 1719 than to those of 1704 .

Some more general sources for Defoe in writing the scenes set in the Far East in The Farther Adventures were the events surrounding the "Worcester affair." The central similarity involves the false accusation that a ship had been engaged in piracy. Captain Thomas Green of the Worcester and members of his crew were so accused after they put into Leith in the Firth of Forth in March 1705. He was accused of having boarded a Darien Company ship, the Speedy Return, off the Malabar Coast and slaughtered its Captain, Robert Drummond, along with his entire crew. To complicate matters, rumor had it (and much in Green's trial was based on rumor) that Captain Drummond and the crew of the Speedy Return had become pirates, whereas in fact the Speedy Return had been captured by the genuine pirate, Captain Bowen, and burned off the coast of India at Rajapur. Captain Green and members of his crew were executed by the Scottish court, despite a lack of firm evidence. 
James Kelly has demonstrated how deeply Defoe was involved in this affair in the Review, in The History of the Union of Great Britain (1709), and in a work that Kelly demonstrates to have been written by Defoe in 1705, Observations Made in England on the Trial of Captain Green. ${ }^{32}$ Defoe allowed his imagination to play over much of this material in The Farther Adventures. Crusoe and his partner, the "English Merchant," purchase a ship that, as matters turn out, was used by pirates. Though he and his partner are innocent, they are pursued by a number of small boats in the Mekong River until they make their escape. They know that if they are captured by these boats, they will be "executed, with very little Ceremony" (176) as pirates. This chase is one of the more exciting episodes in The Farther Adventures, and the problem of somehow avoiding the pursuit of other ships and getting rid of their tainted ship takes up more than thirty pages of text in the first edition. In addition to dealing with the escape and the effort to avoid all ships in the area, these pages include a meditation on the lack of justice in such cases $(182,192)$ and a description of the anxieties produced by the fear of being executed. In the case of Captain Green and his crew, at the time that Defoe wrote on this subject in 1705, he was chiefly concerned that the incident should not become a point of controversy in the negotiations for the union of England and Scotland. He argued the notion that, whether the judgments on Green and his crew were right or not, the trial had been conducted according to the laws of Scotland. Under those circumstances, he did not feel that it should be made an impediment to the union of the two nations. Nevertheless, he was apparently deeply moved by the notion of innocent men being executed, and it emerged forcefully in his imaginative fiction. It would not be wildly speculative to think that Defoe had in the back of his mind those moments in his own career when, imprisoned by the authorities for what he did not consider to be crimes, his own life hung in the balance.

There are other connections related to the Worcester affair. For example, the pirate Captain Bowen, who captured the Speedy Return from Captain Drummond, illegally sold a ship he had captured to merchants in India. ${ }^{33}$ Drummond, the captain of the Speedy Return, was left ashore in Madagascar and narrowly escaped the slaughter of the English seamen at the hands of the natives, an event witnessed by Robert Drury. ${ }^{34}$ Defoe's knowledge of Drury's account is not entirely clear, much less his having had a part in writing it, but whatever knowledge he had of these events, he would have been embroidering imaginatively upon them. In some ways, the "Massacre of Madagascar" in The Farther Adventures reversed these events, with the greater violence being committed by the Europeans. The important point is not so much that there are connections between Crusoe's adventures in Madagascar and events in the Far East but that questions of guilt, innocence, and violence seemed to ripple out of the Worcester affair in all directions and that by the power of his imagination, Defoe was able to bring them together in The Farther Adventures.

The Farther Adventures is a sequel, and like most sequels inferior to the original. Still, The Farther Adventures contains some memorable scenes. The two rescues at sea are dramatic and well realized. The Spanish Captain's account of the 
struggles within the colony with Will Atkins and his followers and then with the cannibals is told in vivid terms. The conversion of Will Atkins and his wife is moving, and if the description of the wickerwork house as a wonder falls far short of the discovery of the footprint in the sand or the mysterious goat in the cave, it has a degree of interest. The escape from being taken as a pirate ship is certainly exciting enough, as is the trip across Siberia, and the "Massacre of Madagascar" is a brilliant and dramatic example of Defoe's descriptive ability at its best. The satiric depiction of China is an amusing set piece-a warning against overestimating the exotic by judging it against the contemporary realities.

To judge The Farther Adventures against a book that achieved instant success throughout Europe and maintained its reputation into the twenty-first century is to do it a disservice. The Life and Strange Surprizing Adventures had a brilliance that could not be imitated. Insofar as The Farther Adventures was often read alongside the initial volume, it may be said that Defoe managed to sustain some of the interest he had aroused with the original. If he replaced the introspection and solitude of the first part with a somewhat disparate series of adventures, it was perhaps all that could have been expected. In some sense, it was a test for Defoe. Could he discover new veins of material that would keep up the interests of his audience? Could he write well enough to please them anew?

The evidence suggests that the second part was successful enough. It went into a second edition soon after publication. Hutchins also asserts that the "number of copies of Part II would appear to have been greater than the number of the first edition." ${ }^{35}$ Since it was thought of as a sequel, it is difficult to treat it as an independent work. Crusoe, the narrator, is always conceived as the same Crusoe who survived close to three decades of despair, isolation, and the cannibals on his island. ${ }^{36}$ Nevertheless, if Defoe's creative genius had already begun to recede toward the end of The Life and Strange Surprizing Adventures, his imagination did not flag entirely. If we lack Crusoe's meditations on his island situation, we are given a series of interesting developments and adventures. If the reader does not possess Crusoe's obsession about seeing how the inhabitants fared after his departure, Defoe at least succeeds in arousing the curiosity of the reader. After all, he had ended the first volume with a promise of further adventures, and if, as E. M. Forster commented, curiosity is not the highest aesthetic value in a novel, it has always been the device that keeps the reader going. ${ }^{37}$ Once Crusoe experiences his compulsion to discover what happened to the island's inhabitants, we do want to know how he ends up and how the island has fared with its odd combination of anarchistic Englishmen and noble Spaniards. Will Atkins may be of more interest as the eternal troublemaker than as the repentant sinner, but contemporary readers probably found his religious progress extremely satisfying. And if the series of adventures that lead to the epic journey across Siberia is somewhat less exciting than Crusoe's fright over the cannibals who visit his island, Defoe still manages to maintain his reader's interest through various devices. For example, the satiric description of China and the Mandarin with whom Crusoe travels represents a welcome change of pace from the adventure sequences. 
He also creates a series of characters who assume some degree of life within the fabric of the adventure story. Besides the Russian Prince, there are the somewhat complex French Priest who marries the English to their native wives, the "English Merchant," whom Crusoe calls his "Partner," who urges Crusoe to a life of active trading, and the "Portuguese Pilot" who rescues Crusoe and his partner by arranging for the disposal of their goods. ${ }^{38}$ The Pilot is given the dramatically ironic role of informing the only too aware Crusoe about the search after a pirate ship by English and Dutch ships. And this old Pilot also rescues Crusoe from a small band of Tatars after Crusoe attempts to purchase a camel in a semicomic scene of commerce and battle. ${ }^{39}$ Yet Defoe tends to drop him as a character and instead introduces the Scots Merchant who helps Crusoe in blowing up the idol. Perhaps Defoe felt he needed someone to balance Crusoe's zeal with a character who shared his distaste and contempt for paganism. In addition to these characters who take on some depth, there are a half dozen other figures who emerge briefly from the text: Father Simon, the priest who travels through China with Crusoe; the impoverished Mandarin who has a pretense to greatness; the servant left to attend Crusoe in Bengal by Crusoe's Nephew; the English Gunner and Dutch Pilot who inform Crusoe about the attempt to capture him as a pirate; and the Cossack who acts the role of misdirecting a group of Tatars pursuing them. Although they are given little psychological depth, Defoe manages to give them a degree of life and even afterlife. For example, Crusoe's servant takes control of the pirate ship in trading to Japan, and the reader is told that he makes a successful voyage across the Pacific to Acapulco and from thence back to England as a wealthy man. In short, Defoe succeeds in creating a convincing novelistic world peopled by characters appropriate to the continual narrative action.

In shaping the character of the Russian Prince, Defoe had the benefit of working with a concrete, historical model. Prince Vasily Vasilievich Golitsyn had served as the equivalent of "prime minister" while Russia was under a form of regency led by the Tsarina Sophia. On 9 September 1689 he barely escaped execution and was subsequently sent into exile. ${ }^{40}$ As presented to the West by writers such as Foy de la Neuville, Golitsyn was a rare kind of personality-a Russian with sophisticated European tastes in art, literature, and architecture. He was depicted as an idealist who admired Louis XIV's France and wanted to bring a degree of civilization to a Russia that, during this time, was extremely insular. Neuville described him as being like an Italian prince in his knowledge and generosity and felt that by his exile Russia had lost all hope of improvement: "If I wished to write down everything which I have learned of this prince I would never be done. Suffice it to say that he wished to people the deserts, enrich the beggars, make men of savages, and turn shepherds' huts into palaces of stone, and that Muscovy has lost everything by the disgrace of this great minister." ${ }^{\prime 41}$ Peter exiled him to an area north of Moscow and later to the region around Archangel. Defoe mentions Golitsyn as someone separate from the Prince, but it is clear that in crafting the character of the Prince, he drew upon the outlines of Golitsyn's story-that of a person who had once been at the very height of power, living a luxurious life, who had sud- 
denly been thrust into the cold wilds of Russia. As Defoe constructs his character, the Prince had found some of the same kind of contentment in his situation that Crusoe had achieved on his island. The Prince regards Crusoe's offer to smuggle him out of Russia as a test of his newfound religious beliefs. He accepts Crusoe's suggestion for his son, but not for himself, regarding Crusoe's proposal as a kind of temptation from the Devil. Idealistic characters are rare enough in Defoe's fictions. ${ }^{42}$ But the Prince is clearly presented as an admirable character-a man of courage, strong convictions, and faith, and aside from Crusoe himself, the richest character in the text.

Still, as has been argued previously, The Farther Adventures is essentially an adventure story, depending more upon the rendering of events and actions than character. To interest his readers Defoe used exotic lands and landscapes along with the dangers involved in encountering savage and barbarian natives. The practice of evoking jungle landscapes with exact description of fauna and flora probably did not enter this form before Bernardin de Saint-Pierre's Paul et Virginie (1788), yet as Virginia Woolf remarked, Defoe had an ability to evoke a landscape with a few strokes of his pen. ${ }^{43}$ If he is able to ignore the lush jungle landscape of India and Cambodia, he does give us a sense of the great wastes of Mongolia and Siberia. He does this not so much by detailed description as by an evocation of deprivation:

... we enter'd a vast great wild Desart, which held us three Days and Nights March, and we were oblig'd to carry our Water with us, in great Leather Bottles, and to encamp all Night, just as I have heard they do in the Desart of Arabia. (220)

After this, we pass'd several great Rivers, and two dreadful Desarts; one of which, we were sixteen Days passing over, and which as I said, was to be call'd no Man's Land; and on the 13th of April, we came to the Frontiers of the Muscovite Dominions ... (225)

We were now launch'd into the greatest Piece of solid Earth, if I understand any Thing of the Surface of the Globe, that is to be found in any Part of the Earth, we had at least twelve hundred Miles to the Sea, Eastward; we had at least two thousand to the Bottom of the Baltick Sea, Westward; and above three thousand Miles, if we left that Sea, and went on West to the British and French Channels: We had full five thousand Miles to the Indian, or Persian Sea, South; and about eight hundred Miles to the Frozen Sea, North ... (226)

From this City we had a frightful Desart, which held us three and twenty Days march. (238)

... I met with nothing peculiar to my self in all this Country, which I reckon was from the Desart which I spoke of last, at least 400 Miles, Half of it being another Desart, which took us up twelve Days severe travelling, without House, or Tree, or Bush, but were oblig'd again to carry our own Provisions, as well Water as Bread. (239) 
Everywhere in these "vast" steppes are the Tatar raiders, adding to the terror of the landscape. Woolf thought Defoe had little of the sublime in his descriptions, but what Defoe evokes is the endlessness and emptiness of the landscape along with feelings of solitude, all painful species of the sublime that she seemed to have ignored. ${ }^{44}$

Defoe also indulges to some extent in the kind of witty images of a frozen land that Scandinavian countries and Russia evoked for poets such as Ambrose Philips, whose "Winter-Piece" (1709) described the oddities of an icy landscape. ${ }^{45} \mathrm{Hav}$ ing arrived at Tobol'sk, Crusoe gives the reader a brief glimpse of this world, which, in general, he tries to avoid by remaining at Tobol'sk for the cold season:

... they told us of Sledges and Rain Deer to carry us over the Snow in the Winter time, and indeed they have such Things, that it would be incredible to relate the Particulars of, by which means the Russians travel more in the Winter than they can in Summer, because in these Sleds they are able to run Night and Day; the Snow being frozen, is one universal Covering to Nature, by which the Hills, the Vales, the Rivers, the Lakes, all are smooth, and hard as a Stone, and they run upon the Surface without any Regard to what is underneath. (241)

Instead Crusoe tells the reader of the ways in which he kept warm in this frigid climate by a central heating plan and the kind of long coats that Peter the Great was trying to banish from Russia. Defoe's subject, exemplified in the story of the Prince, is not so much the cold and landscape as exile and banishment in a land ruled by a tyrant and the spiritual comforts discovered in abandoning the pleasures of the world.

On the whole, then, Defoe tries to interest the reader in the human aspects of the landscape rather than scenery for its own sake. In the episode involving the careening of the ship in a river leading from the Bay of Tonquin and the subsequent attack upon them by native ships, all that we learn of the landscape is that the river was "small" but "had a Depth enough of Water for us" and was close enough to the bay to allow the observation of dangerous foreign ships. On the other hand, Crusoe tells the reader several times about the character of the inhabitants of the region:

The People we were among, were the most barbarous of all the Inhabitants of the Coast; having no Correspondence with any other Nation, and dealing only in Fish, and Oil, and such gross Commodities; and it may be particularly seen, that they are, as I said, the most barbarous of any of the Inhabitants, (viz.) that among other Customs they have this as one, (viz.) That if any Vessel have the Misfortune to be shipwreck'd upon their Coast, they presently make their Men all Prisoners or Slaves ... (183)

The most important thing for the reader to know is the nature of the natives. The size of the river is important only because it helps the ship and the crew escape detection. At times Defoe certainly uses random details to create a sense of the real, but his selection of those details is seldom without some significance. 
After the violent confrontation with the natives, resulting in one death and the maiming of many others, Crusoe draws a moral that is in keeping with his attitude toward a colonialism that was often too negligent toward the lives of the natives:

... I was sick of killing such poor Savage Wretches, even tho' it was in my own Defence, knowing they came on Errands which they thought just, and knew no better; and that tho' it may be a just Thing, because necessary, for there is no necessary Wickedness in Nature, yet I thought it was a sad life, which we must be always oblig'd to be killing our Fellow-Creatures to preserve, and indeed I think so still; and I would even now suffer a great deal, rather than I would take away the Life, even of that Person injuring me: And I believe, all considering People, who know the Value of Life, would be of my Opinion, at least, they would, if they entred seriously into the Consideration of it. (186)

Crusoe will go on to participate in the killing of numbers of Tatars in the journey across Siberia, yet those actions, as indeed the engagement in the river off the Bay of Tonquin, involved self-defense, something Defoe, following Hobbes, regarded as an irresistible principle of human nature. ${ }^{46}$ That is why murder under such conditions could not be considered a form of "Wickedness," since God did not create an immoral nature. Nevertheless, the lesson from these encounters is clear enough for Crusoe. It amounted to a confession that the violence that seemed too often to arise from the contact between Europeans and the natives of foreign lands was ethically unacceptable. Thus The Farther Adventures is far from the pure adventure-story mode. Assuredly, Defoe gives his readers a sufficient number of exciting incidents, but he also demands that they consider the import of such events.

\section{NOTES}

1. Taylor registered The Farther Adventures in the Stationer's Register on 17 August 1719. See Henry Clinton Hutchins, Robinson Crusoe and Its Printing, 1719-1731: A Bibliographical Study (New York: Columbia University Press, 1925; repr., New York: AMS Press, 1967), 40.

2. See Hutchins, 97-121.

3. Defoe puns on the notion of delusional mental wanderings ("wandring Fancies" [9]) and the desire to travel, suggesting, perhaps, a relationship between the two.

4. Samuel Pufendorf viewed such acts as "a lamentable but not a sinful Expedient." See Maximillian Novak, Defoe and the Nature of Man (Oxford: Clarendon Press, 1963), 71.

5. See Michael Fried, Absorption and Theatricality: Painting and Beholder in the Age of Diderot (Berkeley: University of California Press, 1980).

6. For a discussion of gesture and emotion in Dubos and Le Brun, see Alan McKenzie, Certain Lively Episodes: The Articulation of Passion in Eighteenth-Century Prose (Athens: University of Georgia Press, 1990).

7. See Dr. Wild's Humble Thanks for His Majesties Gracious Declaration for Liberty of Conscience, March 15, 1672 (London, 1672), line 87. See also Geoffrey Sill, "The Source of Robinson Crusoe's 'Sudden Joys,'” Notes and Queries 243 [n.s. 45, no. 1] (1998): 67-68.

8. See Charles Le Brun, A Method to Learn to Design the Passions, ed. Alan McKenzie, Augustan Reprint Society 200-201 (Los Angeles: William Andrews Clark Library, 1980).

9. For a discussion of such scenes and their relationship to Robinson Crusoe, see Maximillian Novak, "Describing the Thing Itself, or Not: Defoe and the Art of Describing," EighteenthCentury Fiction 9 (1996): 1-20. 
10. See Daniel Defoe, A Review of the Affairs of France, ed. Arthur Secord (New York: Columbia University Press, 1938), 4:425-426.

11. Although Scott does not have pirates in the sequence of novels devoted to the development of Britain as a nation, thieves such as the title character of his Rob Roy and some of the figures among the Highlanders are certainly lawbreakers.

12. This comment also foreshadows Crusoe's contact with the real Tatars in Siberia toward the end of the novel. Whether Defoe was attempting to suggest a connection or whether he was already imagining the final sections of the novel is difficult to say.

13. For a discussion of this, see Novak, "Describing the Thing Itself," 1-20.

14. Defoe's admiration for Gustavus Adolphus, William III, and Marlborough was an indication of this attitude. For Defoe's tendency toward hero worship, see Maximillian Novak, Defoe and the Nature of Man, 129-154.

15. Percy Adams, in his Travel Literature and the Evolution of the Novel (Lexington: University of Kentucky Press, 1983), 125-130, suggests a number of earlier examples, from Homer's Odyssey to Richard Head and Francis Kirkman's English Rogue.

16. See Ian Watt, The Rise of the Novel (Berkeley: University of California Press, 1957), 30-34.

17. For attempts to exploit the utopian possibilities of this situation, see Charles Johnson, The Successful Pirate (London, 1713).

18. For a comparison of Defoe's protagonist with Kurtz, see Michael Seidel, "Defoe in Conrad's Africa," Conradiana: A Journal of Conrad Studies 17 (1985): 145-146.

19. See for example, Histoire de Sudmer ou Robinson Crusoé (London, 1802). All of these works drew upon the adaptation by the educator Joachim Heinrich Campe's Robinson der Jüngerer (1779-1780), but Campe was interested in teaching morality as well as geography.

20. David Porter, in his essay “'A Peculiar but Uninteresting Nation': China and the Discourse of Commerce in Eighteenth-Century England," Eighteenth-Century Studies 33 (2000): 181-199, sees Defoe's attitude as predictive of the English view of China during most of the eighteenth and nineteenth centuries. England valued commerce and progress; China did not. Hence China was seen as looking backward rather than forward. Robert Markley challenged this idea, suggesting that Defoe and some of his fellow Englishmen felt a sense of inferiority toward China's accomplishments. But whereas the Jesuits who had praised Chinese civilization were oriented toward absolute monarchy, Defoe was an ardent advocate of progress and commerce. Porter seems to have it right; Markley, despite the ingenuity of his arguments, appears to have it wrong. See Markley, "I Have Now Done with My Island, and All Manner of Discourse about It': Crusoe's Farther Adventures and the Unwritten History of the Novel," in A Companion to the Eighteenth-Century English Novel and Culture, ed. Paula R. Backscheider and Catherine Ingrassia (Oxford: Blackwell, 2005), 25-47.

21. See Arthur Secord, Robert Drury's Journal and Other Studies (Urbana: University of Illinois Press, 1961), 31-33; and Secord, "Defoe in Stoke Newington," PMLA 66 (1951): 211-225.

22. See The Letters of Daniel Defoe, ed. George Healey (Oxford: Clarendon Press, 1955), 253-254.

23. See Bowrey, A Geographical Account of Countries Round the Bay of Bengal, 1669 to 1679, ed. Richard Temple, ser. 2, no. 12 (London: Hakluyt Society, 1905).

24. For example, Giovanni Ghirardini’s Relation du voyage fait à la Chine sur le vaisseau l'Amphitrite en l'année 1698 (Paris, 1700) is included in the catalog of The Libraries of Daniel Defoe and Phillips Farewell, ed. Helmut Heidenreich (Berlin: Heidenreich, 1970), 81 (item 1290a). Since two libraries were mingled together and since book auctioneers often added their own miscellaneous stock to catalogs, it is necessary to treat Defoe's ownership of particular books with caution.

25. Both collections appear in the sales catalog of his library. See Heidenreich, 10, 11, 14, 64 (items 133, 142, 196, 1018).

26. Le Comte, Memoirs and Observations ... Made in a Late Journey through the Empire of China (London, 1698), 73, 212.

27. See Louis Le Comte, Lettre à Monseigneur le Duc du Mayne sur les cérémonies de la Chine (Paris, 1700). 
28. An Embassy from the East-India Company of the United Provences, to the ... Emperour of China, 2 vols. (London, 1669). In the line notes, we have identified a number of possible sources that we will not discuss here. For example, a volume by Giovanni Ghirardini, Relation du voyage fait à la Chine sur le vaisseau l'Amphitrite en l'année 1698, may have been in Defoe's library. It is of interest because it is more critical of China than Le Comte. See above, note 23.

29. The exception to the rule is Crusoe's appearance before a Chinese judge in a dispute over a camel. Crusoe loses the case, and although he avoids any general encomium on Chinese law, he has to admit that the reasoning of the judge was entirely correct.

30. Arthur Secord identified Ides as a possible source for Defoe as well as Le Comte. See Studies in the Narrative Method of Defoe (London: Russell and Russell, 1963; reprint of 1924 edition), 63-74.

31. An Imparital History of the Life and Actions of Peter Alexowitz, the Present Czar of Muscovy (London, 1723) and The History of the Wars, of His Present Majesty Charles XII. King of Sweden (London, 1715), usually ascribed to Defoe, treat Peter's military campaigns. The conflict between the two young monarchs of Sweden and Russia began as soon as Peter ended his visit to Europe and returned to Moscow. See Robert Massie, Peter the Great: His Life and World (New York: Knopf, 1980), 289-366.

32. "The Worcester Affair," Review of English Studies, n.s., 51 (2000): 1-23.

33. Charles Johnson, pseud. [Daniel Defoe et al.?], A General History of the Pyrates, ed. Manuel Schonhorn (London: Dent, 1972), 452.

34. See Madagascar: or, Robert Drury's Journal during Fifteen Years Captivity on That Island (London, 1729), 18-61.

35. Hutchins, Robinson Crusoe and Its Printing, $100 \mathrm{n} 1$.

36. Melissa Free has argued that The Farther Adventures was almost always printed with The Life and Strange Surprizing Adventures through the nineteenth century up to World War II and shows that in some editions the two works were merged. She even found one critic who preferred the sequel to the original. See "Un-Erasing Crusoe: Farther Adventures in the Nineteenth Century," Book History 9 (2006): 89-130.

37. Aspects of the Novel (New York: Harcourt, Brace and World, n.d.; originally 1927), 27-30.

38. It may be pointed out that, although Defoe tends to leave these characters with names depicting their status in society or their occupation, such as priest, pilot, prince, in the typography of Defoe's time these characters would have had names with the first letters capitalized, as in Crusoe's friend the "Portugal Pilot" or the character I name the "Prince," whom Crusoe addresses as "My Lord."

39. The image of the good Portuguese is a carryover from The Life and Strange Surprizing Adventures, in which the kind Portuguese Captain acts as his benefactor by rescuing him and helping him in Brazil and later by providing Crusoe with the accumulated riches from his plantation. Defoe may have owned a book that was lavish in its praise of the Portuguese as a generous and valiant people. See Antonio Sousa-de-Macedo, Flores de España Excelencias de Portugal (Lisbon, 1631). See Heidenreich, Libraries, 17 (item 250).

40. Massie, Peter the Great, 80-104.

41. A Curious and New Account of Muscovy in the Year 1689, ed. Lindsey Hughes, trans. J. A. Cutshall, Occasional Papers no. 23 (London: School of Slavonic and East European Studies, 1994), 55 .

42. One example is Roxana's Dutch merchant, who persists in his love for Roxana over many years. Defoe's narratives usually show such an idealistic approach to life as naive.

43. Although Woolf emphasizes Defoe's command of "fact," she comments that "by means of this genius for fact Defoe achieves effects that are beyond any but the great masters of descriptive prose. He has only to say a word or two about 'the grey of the morning,' to paint vividly a windy dawn." Collected Essays, 3 vols. (London: Hogarth Press, 1966), 1:74.

44. For these elements of the sublime, see Edmund Burke, A Philosophical Enquiry into the Origin of Our Ideas of the Sublime and Beautiful, ed. James T. Boulton (Notre Dame, IN: University of Notre Dame Press, 1968), especially 43, 64-74. 
45. A similarly witty type of poem, or series of poems, by George Turberville, specifically about Russia, appears in Hakluyt's Voyages, 8 vols. (London: Dent, 1936), 2:99-108. Turberville recounts the usual oddities from an English standpoint, including the ground becoming so hard during winter that it was impossible to bury the dead. James Thomson's Winter, with its account of Siberia, first appeared in 1726.

46. In his True-Born Englishman (1701), Defoe had written,

No man was ever yet so void of Sense,

As to debate the Right of Self-Defence;

A Principle so grafted in the Mind,

With Nature born, and does like Nature bind:

Twisted with Reason, and with Nature too;

As Neither one nor t'other can undo.

See Defoe, A True Collection of the Writings of the Author of the True-Born Englishman, 2 vols. (London, 1703-1705), 1:27. 